\title{
B Acute Lymphoblastic Leukemia with t(12;21)(p13.2;q22.1); ETV6-RUNX1
}

National Cancer Institute

\section{Source}

National Cancer Institute. B Acute Lymphoblastic Leukemia with t(12:21)(p13.2; q22.1);

ETV6-RUNX1. NCI Thesaurus. Code C80343.

A B-cell acute leukemia characterized by the presence of lymphoblasts that carry a translocation between the TEL gene on chromosome 12 and the AML1 gene on chromosome 21, (p13.2;q22.1). It results in the production of the TEL-AML1 (ETV6RUNX1) fusion protein. It is commonly seen in children and rarely in adults. It has a favorable clinical outcome. 